\title{
THE DEVELOPMENT OF AUTHENTIC PERSONALITY WITH LIMITATIONS OF THE EDUCATIONAL SYSTEM (IN THE EXAMPLES OF FILMS: PROFESSOR VUJIĆ'S HAT, DIRECTED BY Z. ŠOTRA, AND DEAD POETS SOCIETY, DIRECTED BY P. WEIR)
}

\author{
JELENA JARANOVIĆ \\ jelena.jaranovic@gmail.com \\ University of Belgrade, Serbia
}

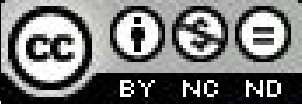

\begin{abstract}
This paper focuses on the urge of young people to find a purpose in their lives and make them more meaningful by insisting on the uniqueness of every individual. It is based on the analysis of two films: Professor Kosta Vujićs Hat (directed by Zdravko Šotra, 2012; based on the novel by MilovanVitezović) and Dead Poets Society (by Peter Weir, 1989). This journey is made through resisting and fighting against rigid rules of the educational system. The metamorphosis is influenced by two extraordinary teachers who give their students motivation and support. We will also consider the role of a teacher in the modern society and the possibility to switch from an ordinary lecturer to an exceptional leader, who encourages these students to look at life from different perspectives by making them question common thinking patterns.
\end{abstract}

Key words: authenticity, identity, rigid school system, teacher roles, novel-based movies, educational system.

\section{INTRODUCTION}

The pursuit of meaning on the path to growing up and maturity is never easy. The discovery of the full scope of one's own personality in the coming-of-age period requires comprehension and support of exceptional teachers: "for education to fulfil its purpose, it is necessary to have educators (...) who are superior to others, noble spirits, who prove this at every moment, with words and silence" (Nietzsche, 2005, p. 52). For this reason, the paper will focus on the impact of teachers on the development and formation of personalities of the students prone to rebellion and reassessment of established values in the context of the traditional school system. The paper will be based on the analysis of two films: Dead Poets Society (Weir, 1989) and Professor Kosta Vujić's Hat (Šotra, 2012; based on the eponymous novel by Milovan Vitezović).

Since a significant part of this paper is dedicated to the concepts of "authenticity" and "identity", we will briefly explain the meaning of these terms, viewing them in a philosophical and psychological context. In existential philosophy, authenticity represents "the first, genuine, original mode of existence which implies that man has assumed responsibility for the choice of true existence" 
(Savić, Cvetković, \& Cekić, 2001, p. 301). We see that this approach stresses the responsibility which an individual assumes by the choices he makes. Particularly hard could be the decisions that need to be reached independently in crisis situations, among contradictory possibilities that are presented. However, having made the decision an individual "recognizes himself as a free being, because with the independent choice of one of the contradictory possibilities he singlehandedly decides what kind of existence he desires" (Savić, Cvetković, \& Cekić, 2001, p. 275).

Despite the fact that the plots of films which are being compared unfold in different social and historical contexts, the issues they tackle are closely related: in both films young men of similar age grow up within a strict, traditional educational system and their lives are substantially influenced by exceptional, extraordinary teachers who with their pedagogical approaches expand the rigid framework of the school system. In both cases teacher's influence produces a similar result - it encourages freedom and students' creative spirit, thus influencing the clearer discovery of their own identities and the establishment of individual value system. Therefore in this paper we will try to determine what effects can be caused by teachers willing to confront the established system and to what extent they can be far-reaching. What happens when formal knowledge acquisition within traditional school system is replaced with a new goal - the development of students' independent and critical thinking? In what ways do newly established frameworks shape the lives of students who embraced a new scope of freedom?

Characters in both films are in their formative years, at the end of high school. Psychological maturing during puberty is most commonly accompanied by identity crisis: "This life stage could not be completed without identity finding the form which would later crucially determine the individual's life" (Erickson, 1976, p. 77). It can be concluded from the abovementioned that considerable impact can be made by people who have the ability to influence young people during this formative period. Erik Erickson later states that "a young person in puberty will fervently search for credible people and ideas (...). He now seeks the ability to make decisions with free acceptance“ (Erickson, 1976, p. 108). We see that the development of identity, as well as authenticity, goes through the inevitable process of acquiring independence in reaching decisions and assuming responsibility for them. In the case when the environment impedes the attempts of young people to find their individual expressions "they will defend themselves with wild force likely to be found in animals who are suddenly compelled to fight for their own lives" (Erickson, 1976, p. 109). An explicit example of such reactions is seen in the conduct of American boys who, having accepted their interpersonal differences as a value, refuse to re-conform to uniformity of the system. E. Erickson concludes: "For, indeed, in the social jungle of human existence, one cannot feel alive without a sense of identity" (Erickson, 1976, p. 109).

It is essential to underline the reason why the paper will predominantly focus on films rather than literary works. In the past few decades film has had a crucial influence on school population. Therefore, the influence which film exerts today 
on young people is increasingly disproportionate to the influence which books once had: "the youth of today do not have passionate relation to books, children prefer comics, film and television" (Radović, 2006, p. 414). Visual arts are much more accessible, as they require considerably less time and effort from the user: "identification with visual arts is faster, more immediate than a book" (Opačić, 2011, p. 158), which fully reflects the spirit of the modern age. However, it should not be disregarded that film and literature can be strongly intertwined. Often a film that is based on a literary work gives a strong incentive for re-reading, or the initial reading of the literary work. In that way "visual culture has become an unlikely medium for promoting literature as the most beautiful spiritual adventure" (Opačić, 2011, p. 157). This is the case with the film and novel Professor Kosta Vujić's Hat. The opposite case is less common, when a film, which is exceptionally influential and inspiring, spawns a literary work, which is the case with the film and novel Dead Poets Society (in the same year Nancy H. Kleinbaum published the eponymous novel based on the film).

Both films that we mention have achieved great box office success and earned awards: Dead Poets Society is a cult American film which, among other awards, earned an Oscar for the best screenplay, while Professor Kosta Vujić's Hat is one of the top-grossing Serbian films of all time - within the first three weeks of its release, the film had over 100, 000 viewers (VESTI online, 2012). The reception of the film is illustrated by the words of the author and screenwriter Milovan Vitezović, - "the story of professor Vujić restored our national pride" (Lopušina, 2012). Consequently, the impact of these two films is far from negligible.

The plot of the film Dead Poets Society takes place in 1959, in a private school for boys, with a reputation of the best college preparatory school. The film focuses on life stories of several boys from affluent American families and the changes occurring at school and within themselves under the influence of their new English teacher, who is an alumni of the same school.

The plot of the film Professor Kosta Vujićs Hat takes place in Serbia at the end of the 19th century, or more precisely, in 1886. It depicts a group of young men during their final year at prestigious First Belgrade High School For Boys. It is important to mention that the characters were based on historical figures, namely, some of the finest Serbian scientists ${ }^{1}$ emerged from this generation of high school graduates. Therefore, young Serbian viewers who are familiar with scientific accomplishments of the people portrayed in the film find it interesting that they are represented as young men prone to mischief in order to demonstrate their intellectual independence and rebellion against the school system and social context in which they are formed. They find support and comprehension of their efforts in their form master, German language teacher, Kosta Vujić.

\footnotetext{
First High School For Boys (Today: First Belgrade High School) is one of the most prestigious high schools in Belgrade. It was founded in 1839 and was attended by some of the most eminent Serbian scientists, artists and statesmen, such as: Mihailo Petrović Alas (mathematician), Jovan Cvijić (world-renowned geographer), Laza Lazarević, Stevan Sremac, Vojislav Ilić (distinguished Serbian writers), Stevan Mokranjac (composer of Potpourri), Kornelije Stanković (composer and music pedagogue), Živojin Mišić, Stepa Stepanović, Radomir Putnik (distinguished generals and commanders), etc.
} 


\section{DEAD POETS SOCIETY - TEACHER AS A CHANGE INSTIGATOR}

The opening scenes of Peter Weir's film introduce us to the strict discipline and hierarchy in the private high school based on the following principles: tradition, discipline, honour, excellence. We soon realize that students do not fully endorse the values promoted by the school and confront them with anti-values: travesty, horror, decadence, excrement. This secret rebellion reaches its full impulse with the appearance of the new English teacher, Mr Keating2.

Keating himself is an alumni of this school. Since he survived Welton and went through the rigid set of rules imposed on the students, he allows himself to look upon the school in the context of parody from the teaching position which he now holds, calling it Hellton ${ }^{3}$ (as in the days when he was a student there). Keating is a representative of a new education paradigm. Instead of strictly following prescribed curriculum and giving routine lectures - he believes that the purpose of education is to teach young people how to think independently: "I always thought the idea of education was to learn to think for yourself" (Keating, Dead Poets Society, time: 01:19). This is particularly evident in two scenes. First, when he demands that the students tear out introduction from the textbook on English poetry, which claims that art can be valued through previously established algorithm. In such moments we see confusion and discomfort in some students, as a consequence of a clash of values brought about by dual authority: the new teacher on the one hand, and the traditional school system on the other. Secondly, when he requires that the students stand on their desks and look at their surroundings, thus illustrating, in a simple and plain manner, that they must never forget to look at things from different angles and think critically about reality: "I stand upon my desk to remind myself that we must constantly look at things in a different way" (Keating, Dead Poets Society, time: 00:43).

Besides independent thinking, Keating is trying to incite and awaken the sense of value of each moment among his students. Facing them with bygone generations of Welton, he underlines the dangers that are looming if we do not respect the time in which life passes. One of the most memorable scenes in the film is confronting the present moment with the past, and also with transience. Keating says: "Because we are food for warms, lads. Because believe it or not each and every one of us in this room is one day going to stop breathing, turn cold and die" (Keating, Dead Poets Society, time: 00:14). Present will soon turn to past. As the only logical conclusion, as an imperative, comes the need to live each day to the fullest. This also becomes the leitmotif of the film: Carpe diem $!^{4}$ Keating additionally emphasizes this motif by quoting Herrick's (1648) verse, from the poem To the Virgins, to Make Much of Time, which greatly illustrates his point on transience:

Gather ye rose-buds while ye may,

Old Time is still a-flying;

And this same flower that smiles today

Tomorrow will be dying.

Played in the film by Robin Williams.

Word play: Welton / Hellton.

Carpe diem! (Lat.) - Seize the day! 
We see quite clearly from the abovementioned that Keating can by no means be characterized as an "ordinary" teacher. His dedication to his profession and the mission he took upon himself bears a great burden of responsibility. The responsibility which is reflected in the fact that, having shown his students the vast space of personal freedom, having shown them the uniqueness and value of each individual, he is trying to prepare them for the fight awaiting them against the surrounding system. And the system is in this film symbolized by the school principal, who represents the guardian of the old set of rules and tradition, not allowing any of the established values to be questioned. He defends his negative view on the changes Keating is trying to introduce with the argument that the established curriculum which the school is following gives results, and thus that it should, by no means, be altered. This attitude is clearly shown in following reply to Keating: "Well, John, the curriculum here is set. It's proven. It works. If you question it, what's to prevent them from doing the same?" (The principal, Dead Poets Society, time: 01:19).

It is evident that for the boys Keating represents a person they can trust and that he holds ideas that are acceptable for them. This is, according to E. Erickson, significant help to young people in the process of the development of their own identity (Erickson, 1976, p. 110). As a result of his impact we notice changes occurring in each young character. Neil discovers that he truly enjoys acting and that it is the career he wants to pursue. He decides to confront his authoritarian father and persists in it. Todd discovers that, behind shyness and timidity, lies a great writing talent, while Charlie boldly publishes an article in the school magazine on why Welton should be turned into a co-educational school. Knox bravely expresses his affection to a girl he has a crush on, despite the derision from her social milieu. One of Knox's replies, after he read the poem he had written to the aforementioned girl in front of her whole class, perfectly illustrates to what extent these young men accepted the life philosophy to which they were exposed. When other friends ask him how the girl reacted to such bold expression of his affection - he replies that she did not react at all adding, very cheerfully: "She didn't say anything. But I did it!" (Knox, Dead Poets Society, time: 01:28). Knox stresses that it is crucial that he found the courage to put his idea into practice, and not how the girl reacted to it. The climax of the film is Neil's suicide, a tragedy which occurs due to the profound discrepancy between Neil's new views on life and the categorical refusal of his father to accept the decisions that his already mature son wishes to make regarding his own future.

The moment in which we witness the real maturity of these young men is when they individually, and then all together, at least symbolically oppose the unjust system which stifles freedom and deprives them of the opportunity for rebellion, which occurs at the very end of the film. This is also the moment which "acknowledges" Whitman's poem O, Captain! My Captain! (Whitman, 1865) with which the students saluted Keating throughout the entire film:

O Captain! my Captain! our fearful trip is done,

The ship has weather'd every rack, the prize we sought is won

... 
The ship is anchor'd safe and sound, its voyage closed and done, From fearful trip the victor ship comes in with object won;

Exult $O$ shores, and ring $O$ bells!

But I with mournful tread, Walk the deck my Captain lies, Fallen cold and dead.

Like Lincoln, who was assassinated after he had secured the abolition of slaveryby order of southern slave owners, Keating, pressured by the principal, has to leave the school premises and his students. However, despite tragic circumstances, his goal has been accomplished: his protégés became mature and independent, ready to state their opinions and defend their decisions. The Captain is leaving the ship, but the ship has already reached the shore. What is done cannot be undone and these young men, having found the meaning and purpose of their own identification process, cannot revert to the previously established framework within the stifling system, nor can they renounce freedom that they have experienced.

\section{PROFESSOR KOSTA VUJIĆ'S HAT - TEACHER AS A SUPPORTER OF YOUTH REBELLION}

Vitezović's novel Professor Kosta Vujićs's Hat was filmed twice, in 1971 (Andrić, 1971) and 2012 (Sotra, 2012)5. Both works faithfully adhere to the plot of the novel, which is represented as a sequence of humorous anecdotes.

Specific for this novel, as well as the film, is the relation between reality and fiction. "The illusion of a documentary, authentic testimony is enhanced by Vitezović's skill to revive young high school students and future scholars within a literary work 6 ...) In this manner history enters literature and actual people become, as characters, revived subjects of collective memory" (Pijanović, 2005, p. 251). The documentary quality of this work is corroborated by Mihailo Petrović Alas's memoirs, in which he, reminiscing on his high school days, says: "It is impossible to resist the temptation of reviving memories of the old and original teacher whom we all truly loved" (Petrović, 1997, p. 202), referring to Kosta Vujić.

In contrast to Dead Poets Society, where the characters shape and discover their true identity throughout the film with teacher's guidance and encouragement, here we find already developed young people, clearly defined and different from each other. These open-minded young men, partly out of inherent youthful need for mischief, and partly out of serious rebellion against social norms, constantly

\footnotetext{
We will refer to this film version or the original text from the novel.

6 Main characters found in the novel (and the film) are based, as we mentioned, on historical figures: Mihailo Petrović Alas (1868-1943), academician and one of the most renowned Serbian mathematicians, who obtained his PhD degree at Sorbonne University in the field of differential calculus, studied literature and was a passionate angler, hence his nickname; Jovan Cvijić (1865-1927), world renowned geographer, founder of anthropogeography, president of The Serbian Royal Academy (today: SANU) and rector of the University of Belgrade; Jaša Prodanović (1867-1948), academician, writer and Minister of Education; Pavle Popović (1868-1939), academician, rector of the University of Belgrade and literary historian; Milorad Mitrović (1867-1907), distinguished Serbian poet.
} 
come into conflict with the traditional school system. The inflexible educational system is in both works represented through the characters of school principals, the guardians of traditional educational frameworks which require a strict and unconditional obedience to rules. In Dead Poets Society the principal insists on the consistent implementation of the established school curriculum and does not allow for any creative digressions. Caring merely about form, the principal in Z. Šotra's film describes the class of exceptional students as "unruly", being unable to recognize the value of the generation in front of him.

Kosta Vujić ${ }^{7}$ finds himself right between these two worlds. Trying to justify his students' actions before the principal who demands strict discipline, punishment and reform, Vujić mitigates bad influence and the pressure of traditional school system, providing his students with space and freedom for personal expression. How far-reaching Vujić's viewpoint was compared to the principal's ${ }^{8}$ is affirmed in his words: "I taught them German in various ways, but something tells me, Mr. Principal, that in the future you and I will be known only as their teachers" (Vitezović, 1997, p. 105). Behind the arguments with which he defends his students stands his great trust in them as well as the willingness to persist in protecting them. As the main value of this generation, Vujić stresses the very thing that Keating, in Dead Poets Society, strived to reach the whole time - free, independent and critical thinking. Addressing the principal, Vujić says: "This is the generation that will equal Europe (... ) I am not deluded by them. There are plenty of things that they don't know. No generation acquires everything. But these students have learned how to think, I can guarantee that" (Vitezović, 1997, p. 21-22). From this quote it becomes clear that professor Vujić is the kind of teacher who gives "moral support" and "backbone for positive direction" (Pijanović, 2005, p. 253) since he can recognize the signs of excellence among his students and help them on their way to self-accomplishment.

Compared to Dead Poets Society, the atmosphere in the film is cheerful, filled with humorous remarks and puns through which we follow students' innocent attempts at outwitting their teachers. In such scenes we see that the final year students and professor Vujić developed genuine respect and friendship, which is affirmed in Mihailo Petrovićs memoirs: "We immediately saw that he was a kind and sympathetic man who understood children and was benevolent to their mischief" (Petrović, 1997, p. 202). He supported their rebellion against the system, was at times astonished by their wit, was sometimes furious because of their haste and boldness, but he always stood by them, showing that he recognized their true value. To what extent he realised all this is indicated in a reply to young Alas at the end of an argument: "May you, one day, become an academician, so that you'll have to weigh each word several times before you utter it" (Vitezović, 1997, p. 18). In the film Alas replies to this with a sentence that does not appear in the novel: "And I will become an academician!" (Alas, Professor Kosta Vujićs Hat), with the

Played by Aleksandar Berček.

8 When the principal demands the destruction of a (politically) inappropriate book before he has even read it, Vujić sarcastically replies: "At least read it first (...) To know what you have burnt (...) It is good to know from what we have saved our students!" (Vitezović 1997: 21) 
others behind him adding, each for themselves, "Me, too", which wittingly implies future historical events. They did become academicians. Explaining to them at the end of their high school education that life is a collection of anecdotes, Vujić says: "You have to become important people so that the anecdotes from your life are important!" (Vitezović, 2007, p. 94). With these words, Vujić anticipates the success awaiting this extraordinary generation.

We notice that even such relatively passive approach of a teacher who can recognize and support inclinations and skills of his students also has a positive effect on the formation of these young people, as it represents "a reliable guideline to young people on the crossroads of life" (Pijanović, 2005, p. 253). And furthermore: "Youthful zest and intelligence inspired by professor Vujićs kindness and wisdom facilitate young people's first steps into adult life" (Pijanović, 2005, p. 260).

Comparing the methods that Keating and Vujić use and their approach to students we notice remarkable differences. While one is firm in his intentions to draw his students closer to his views on life and inspire and encourage them to try to develop independent personalities, the other supports the activities with which his students oppose the system by showing trust and restrained approval. The goal is reached by both, albeit through different paths: to teach young people to think independently and be responsible for their views and actions. To encourage them to discover and accept their individuality. To assist them in stepping into maturity.

Apart from the teachers who are opposing traditional systems to which they belong, these films have several other intersecting points. Both plots are located in schools for boys and in both films we see endevours to overcome the issues that such exclusively male surroundings impose in the coming-of-age period. In Dead Poets Society we mentioned Knox and the girl he is trying to impress. In Professor Kosta Vujić's Hat one student (Mitrović, future poet) is courting the daughter of the Minister of Internal Affairs by singing serenades under her window. This "case" is reported to the school principal, who demands severe punishment, interpreting this as a detrimental act to school reputation, whereas Vujić, overwhelmed by his own youthful memories, shows comprehension for such romantic acts and refuses to punish the student.

While the Serbian film was based on cheerful and humorous anecdotes which succeed one another, in the American film we witness a harsh and tragic ending which further stresses how difficult it is to fight for personal values in the system which curbs all forms of diversity.

\section{CONCLUSION}

Has the school system today, at the beginning of the $21^{\text {st }}$ century, been able to deal with the issues that were analyzed in the paper? Despite a few initiated reforms, the current school system in Serbia is still quite rigid and unadjusted to students' needs and to a great extent lags behind contemporary social and technical advances. It is true that the educational system is cumbersome and thus inert, requiring more time for significant changes to take place. Still, the only way to make changes is for the people who are a part of the system and make it function 
to start to observe it critically and re-examine it. Only if various individuals dare to question the established values, as Keating and Vujić did, each in his own way, we can expect that the school system will come closer to achieving its goal - the creation of people capable of independent thinking and responsible actions.

\section{REFERENCES}

Andrić, V. (Director), Andrić, V. \& Vitezović, M. (Writers). (1971). Sesir profesora Koste Vujica [Professor Kosta Vujić's Hat] [Motion picture]. Serbia: Radiotelevizija Beograd Film.

Erickson, E. (1974). Identity: Youth and Crisis. Titograd: NIP Pobjeda.

Herrick, R. (1648). To the Virgins, to Make Much of Time. Retrieved from http:/ / www.poetryfoundation. org/poem/175882.

Lopušina, M. (2012). Vitezović: Šešir Koste Vujića vratio ponos Srbiji. Večernje novosti online. [The Evening news online] (2012, 17. March). Retrieved February 20, 2013 from http:/ /www.novosti.rs/vesti/kultura.71. html:371121-Vitezovic-Sesir-Koste-Vujica-vratio-ponos-Srbiji.

Nietzsche, F. (2005). Twilight Of The Idols Or How To Philosophize With A Hammer. Belgrade: Čigojaštampa. Opačić, Z. (2011). Naïve Consciousness and Fiction. Novi Sad: Zmajeve dečje igre.

Petrović, M. (1997). High School Memories. In: P. Pijanović (Ed.). Metaphors And Allegories (pp. 197205). Belgrade: Zavod za udžbenike i nastavna sredstva.

Pijanović, P. (2005). Naïve Story. Belgrade: Srpska književna zadruga \& Teacher training faculty in Belgrade.

Radović, D. (2006). Baš svašta (sabrani spisi) [Just everything (collected works)]. In: M. Maksimović, \& D. Petričić (Eds.). Belgrade: Zavod za udžbenike i nastavna sredstva.

Savić, M., Cvetković, V., \& Cekić, N. (2001). Philosophy. Belgrade: Zavod za udžbenike i nastavna sredstva.

Šotra, Z. (Director/Writer) \& Vitezović, M. (Writer). (2012). Professor Kosta Vujić's Hat [Motion picture]. Serbia: Košutnjak Film.

VESTI online (2012, 23. February). Padaju rekordi: "Šešir" videlo 100.000 ljudi!. Retrieved February 25, 2013, from http:/ / www.vesti-online.com/Scena/Film/204942Padaju-rekordi-Sesir-videlo-100000-ljudi

Vitezović, M. (1997). Professor Kosta Vujić's Hat. Belgrade: Zavod za udžbenike i nastavna sredstva.

Weir, P. (Director) \& Schulman, T. (Writer). (1989). Dead Poets Society [Motion picture]. United States: Touchstone Pictures \& Silver Screen Partners IV.

Whitman, W. (1974). Vlati trave (izabrane pesme). [Leaves of Grass (Selected poems)]. In: I.B. Lalić (Ed. \& Trans.). Belgrade: BIGZ.

Whitman, W. (1865). O, Captain! My captain! Retrieved from http://www.poetryfoundation.org/ poem/174742. 